\title{
○柵木美紀"，西田裕明"，岡田 真由美2)、田中康夫"
}

獨協医科大学越谷病院耳鼻咽唉科" 獨協医科大学耳鼻咽唉科 ${ }^{2}$

（目的） $1 \mathrm{kHz}$ の短音刺激によるCMの記録によってCM類似の遅延反応が同時に記録され、両 者は入出力曲線やAnoxia 負荷に対して異なった反応を示すことを私共は既に報告してきた。 今回は、本遅延反応の本態を解明する目的で種々の刺激周波数を用いAnoxia 負荷時の CM の 波形の解析を行った。

(対象と方法) プライエル反射陽性のモルモットにウレタン腹腔内注射による麻酔後、気管切 開を施行し、CMを正円空誘導法により記録した。音刺激は、イヤホンに接続した硬質のプラ スチックチューブ (径 $2 \mathrm{~mm}$ 、長さ $25 \mathrm{~mm}$ ) を骨部外耳道に密着させて与えた。刺激として立ち 上がり立ち下がり時間各 $1 \mathrm{~ms}$ 、総持続時間 $3 \mathrm{~ms}$ (ただし総持続時間を $0.5 \mathrm{kHz}$ は $7 \mathrm{~ms} 、 0.8 \mathrm{kHz}$ は $4 \mathrm{~ms}$ とした）の短音を用い、刺激周波数として $0.5 \mathrm{kHz}, 0.8 \mathrm{kHz}, 1.5 \mathrm{kHz}, 2 \mathrm{kHz}, 4 \mathrm{kHz}$,

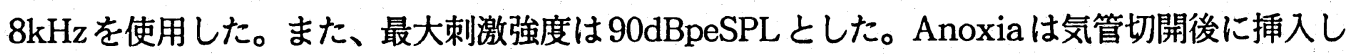
たチューブを閉塞することにより行い、負荷時間は 2 分間とした。短音発生には音刺激装置 SSS-3100改良型 (日本光電) を用い、CMの测定および解析にはシグナルプロセッサER1100 （日本電気三栄）を使用した。

(結果) (1)反応波形：CMの記録において、0.8kHz，1.5kHzおよび $2 \mathrm{kHz}$ では全例において刺 激周波数と同じ周波数成分をもった反応 (CM) とそれより遅れて記録される反応すなわち遅 延反応とが記録され、これらの刺激周波数では刺激強度を順次弱くしていく亡、遅延反応の出 力電位がCMより大きくなり、かつ見かけ上CMが遅れをもって記録されたような反応波形が 得られた。なお、0.8kHz, $1.5 \mathrm{kHz}, 2 \mathrm{kHz}$ における遅延反応の周波数成分は、各々約 $1025 \mathrm{~Hz}$,

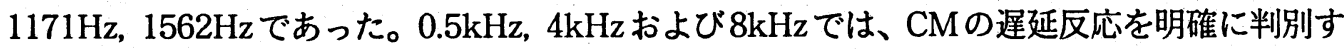
ることは困難であった。代表例を図1に示した。

(2)Anoxia負荷 : 反応波形において、遅延反応が明らかに認められる音圧でAnoxia負荷を行 った時の各刺激周波数における $\mathrm{CM}$ と遅延反応の波形の変化を観察し、振幅の変化を測定し

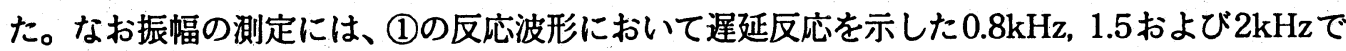
はCM として正の極性の第 2 ピークを、遅延反応として $0.8 \mathrm{kHz}, 1.5 \mathrm{kHz} て ゙ は$ 第 5 ピークを、 $2 \mathrm{kHz}$ では第6ピークをそれぞれ計測した。その結果、これらの刺激周波数における反応は、 CMおよび遅延反応とも Anoxia負荷後ほぼ2分で最も小さくなったが遅延反応の減少率はCM のそれより更に大きくその反応は 90 秒ではほとんどの例において背景雑音レベル内にあり反 応を捕らえることができなかった。図 2 にAnoxia 負荷による代表例の波形の変化と振幅の変 化率を示した。

(まとめ) $0.5 \mathrm{kHz}, 0.8 \mathrm{kHz}, 1.5 \mathrm{kHz}, 2 \mathrm{kHz}, 4 \mathrm{kHz}, 8 \mathrm{kHz}$ の短音刺激によるCMおよびAnoxia 負荷時の波形の变化を記録した。 $0.8 \mathrm{kHz}, 1.5 \mathrm{kHz}$ および $2 \mathrm{kHz}$ ではCM と遅延反応を明暸に区

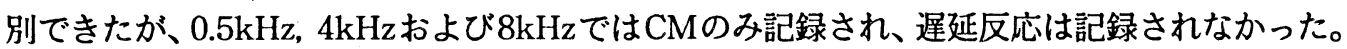
これらの所見より、遅延反応は $1 \mathrm{kHz}$ 近边の刺激周波数によって出現しやすく、かつAnoxia により CM と較べsensitiveであった。 
<反応波形 > 図 1

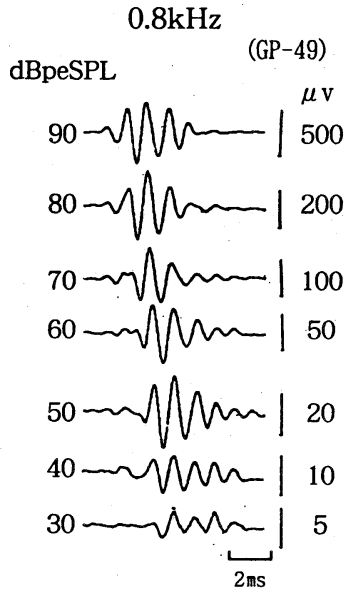

$0.5 \mathrm{kHz}$

(GP-44)

dBpeSPL

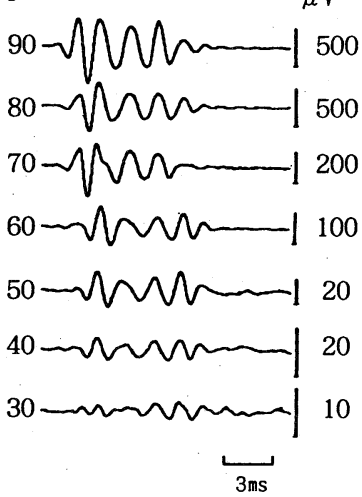

< Anoxia負荷 > 図2

$0.8 \mathrm{kHz} \quad 90 \mathrm{dBpeSPL} \quad(\mathrm{GP}-44)$

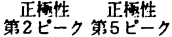

具荷前 VרM $100^{100}$ 30秒 VWm ${ }^{102.6}{ }^{95}$

${ }^{60}$ 和 ${ }^{33.3}$

${ }^{90}$ 秒的

2分的33.3

2分30秒调

5分 W ${ }^{125.6}$

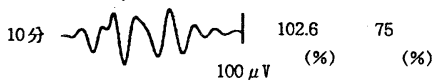

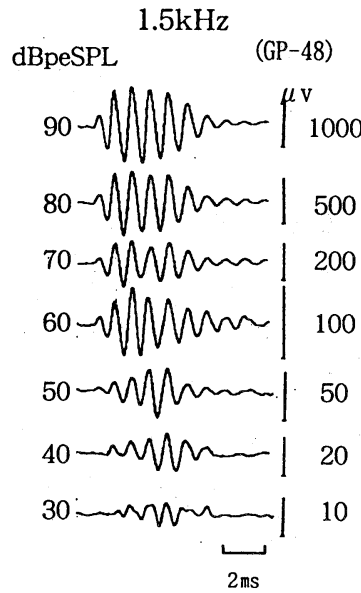

$4 \mathrm{kHz}$

(GP-49)

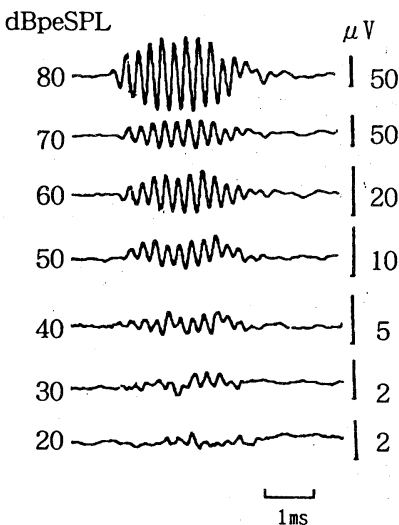

$1.5 \mathrm{kHz} \quad 80 \mathrm{dBpeSPL} \quad(\mathrm{GP}-44) \quad 2 \mathrm{kHz} \quad 80 \mathrm{dBpeSPL} \quad(\mathrm{GP}-46)$ 正灀性、正懦性， 目荷前-WWW 100 3010 PWMm 107.7 106.9 ${ }_{601}^{601}{ }^{51.7}$ 90 种 $\quad 50 \quad 10.3$

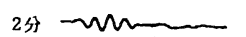

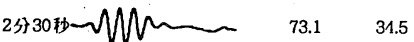
5分 DPflun ${ }_{100} \quad 100$

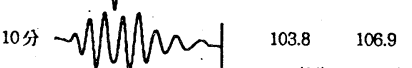

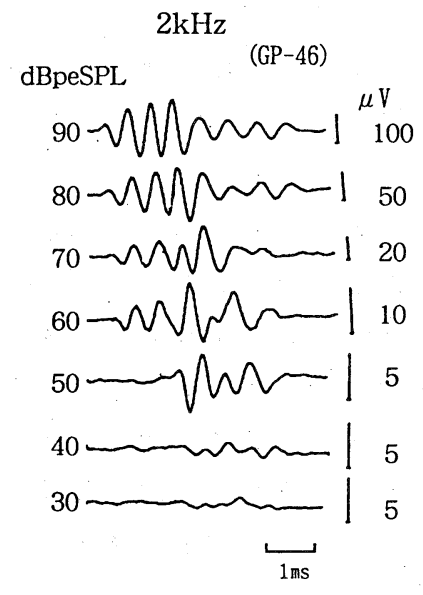

$8 \mathrm{kHz}$

(GP-50)

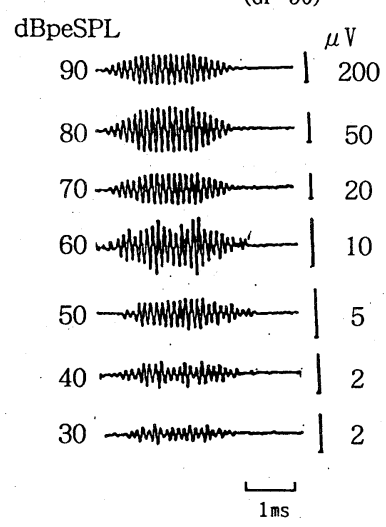

